\title{
二,三の補剛アーチ橋の解法
}

$\begin{array}{llll}\text { 正員 } & \text { 平 } & \text { 井 } & \text { 敦* } \\ \text { 正員 } & \text { 倉 } & \text { 西 } & \text { 茂** }\end{array}$

\section{ANALYSIS OF ARCH BRIDGES WITH STIFFENING GIRDERS}

\author{
Dr. Eng., By Atsushi Hirai, C.E. Member and Dr. Eng., Shigeru \\ Kuranishi, C.E. Member
}

Synopsis: In this paper, the authors carry out the analysis of stiffened arch bridges, which are composed of an arched chord and a stiffening continious beam or rigid frame. Taking panel point moments as a group of statically indeterminate ones, they obtain the fundamental elastic equations applying Castigliano's theorem, and induce the moment distribution factors to the stiffening girder and arched chord, making use of matrix operation. The other statically indeterminate ones are easily calculated using these distribution factors.

Besides them, they discsus here the influence of shifted supporting point of stiffening girder from the vertical line through the supporting point of arched chord at the ordinary stiffened arch(so-called Lohse Traeger).

要 旨 本論文は連続梤またはラーメン枍の一径間をアーチで補剛した型式の補剛アーチ橋の解法を取り 扱つたものである。Castigliano の定理を用いて, 基礎弾性方程式を求め matrix operation を利用して補 㴊枌とアーチ部に対する曲げモーメントの分配率を与光た。この分配率を利用することによりこのような型 式の補剖アーチ橋は比較的簡単に解くことができる。また同様の考方方を用い上路式口一ゼ枌の補剛枌支点 がアーチ支点の鉛值線上にない場合の影響を論じた。

\section{1. 序 論}

アーチ橋に曲げ剛性をもつた桁を両端ピンの垂直材でもつて結合して得られる補剛アーチ橋の型式には種々の るのが考光られる。図一1 と示した三径間連続枌の中央径閒をアーチで補剛したような型式の補剛アーチ橋は支 点モーメントの影響により, 中央径間は 弾性固定アーチのようになり応力が軽 減されると共に，アーチ部の弾性安定を よくする。また立体構造となつているた め, 側方への変形招上びねじれに対して も一般の 2 ヒンジアーチより剛性を大 きくすることができる。構造的とる中間 橋脚を省略することができる。床組の取 りつけが簡易である等の多くの利点をも つている。

この型式の枌は高次の不静定構造物で はあるが，アーチ部と補剛啝に対する曲 げモーメントの分配は matrix operation を利用するととにより近似的にではある が簡単に求めることができ，それらを利 用することにより容易に応力解析が行兄

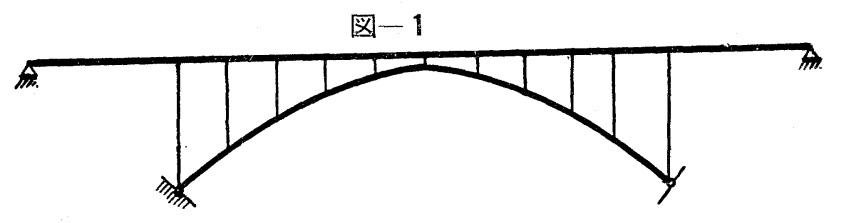

図-2
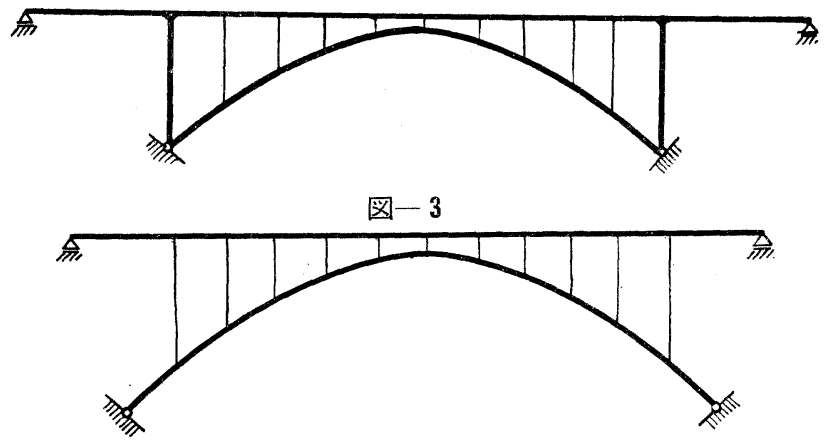

る。また補剛桁としては上記のようと連続析ばかりでなく図一2亿示したようなラーメン構造も利用でき全く同 じような取り扱いができる。これらと少し性質を異にするが上路式ローゼ桁の補剛桁支点がアーチ支点上にない 場合(図一3)の影響についても論ずることにする。これらの型式の補岡アーチ橋はV 字型の谷に架設するのにも 
つとも適したものと思われる。写真一 1 は本理論によつて設計した三坂大橋である。

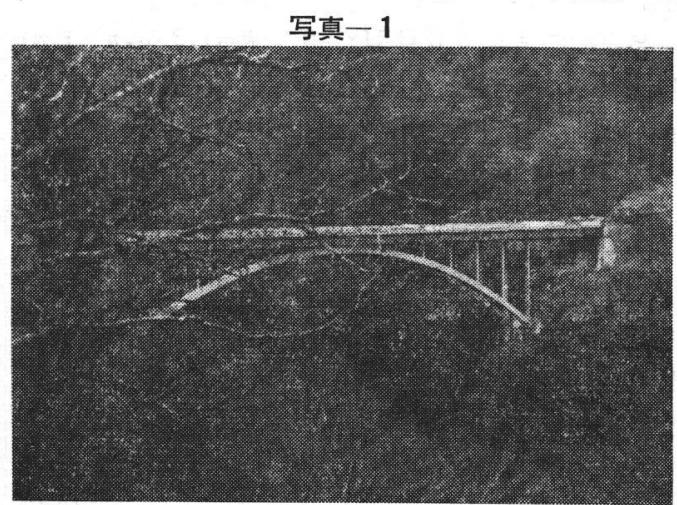

捛もな記号

$L$; 中央径間の支間長, $\lambda$; 格間長, $n+1$; 格間数 $U_{k}$; 中央径間 $(k-1)(k)$ 飞括けるアーチ部材長 $F_{k}^{u}$; " " " アーチ部材断面積
$J_{k}^{u} ;$ 中央径間 $(k-1)(k)$ マ アーチ部材断面 2 招ける次モーメント

$J^{\circ}{ }_{k}$;" " " 補剛析断面 2 次モ $\beta_{k} ; \quad$ " " $"$ アーチ部材が基線

$h_{k} ;$ 格点飞颃けるアーチの高さ

となす角

$J_{c}$ ；任意飞基準として定めた 標準断面 2 次モーメン 卜

$O_{k}{ }^{\prime}=O_{k} \frac{J_{c}}{J^{\circ}{ }_{k}}, U_{k}{ }^{\prime}=U_{k} \frac{J_{c}}{J_{k}^{u}}, l_{k}{ }^{\prime}=O_{k}{ }^{\prime}+U_{k}{ }^{\prime}$

$L^{\prime}, L^{\prime \prime}$; 格点 0 , 格点 $n+1$ 側の側径間長

$M^{\circ}{ }_{k i}$; 補剛析格点モーメントの影響線縦距

$M^{u}{ }_{k i} ;$ アーチ部格点モーメント影響線縦距

$\mathfrak{M}_{k i}$; 単純リとしての曲げモーメント影響線縦距 $Z_{k i}$; 支柱応力影響線縦距

$H_{i} ; \cdots$ アーチ部に㗢く水平反力影響線縦距

$M_{0 i}, M_{n+1, i}$; 支点モーメント影響線縦距

指標 $k i$ は $i$ 点に単位荷重が載荷されたとき $k$ 点と生じるそれぞれの応力を表わす。側径間の場合は $k^{\prime}, i^{\prime}$ ， $k^{\prime \prime}, i^{\prime \prime}$ で表わす。解くにあたり次のごとき仮定を設ける。

a ）格間長は中央径間にわたり一定とする。

b) 中央径間は垂直軸に対し対称とする。

c ）桁は変形後も変形前と同じ力の釣合状態を保つ。

d）格点モーメント，支点モーメントは共に部材を下方に変形さするのを正とする。

\section{2. 補剛析に連続桁を用いた場合の解法}

\section{(1) 格点モーメントの算出}

不静定量としてアーチ部各格点に㗢く格点モーメント $M^{u}{ }_{k i}(k=1,2 \cdots n)$ と両端に働く水平反力 $H_{i}$ と支点 モーメント $M_{0 i}, M_{n+1, i}$ をとる。これらの不静定力が作用している点で拘束をとり，図一 4 亿示したような静定 構造物に前記の不静定力がそれぞれの境界条件を満足するように働いているすのとしょう。一般にローゼ枌の解

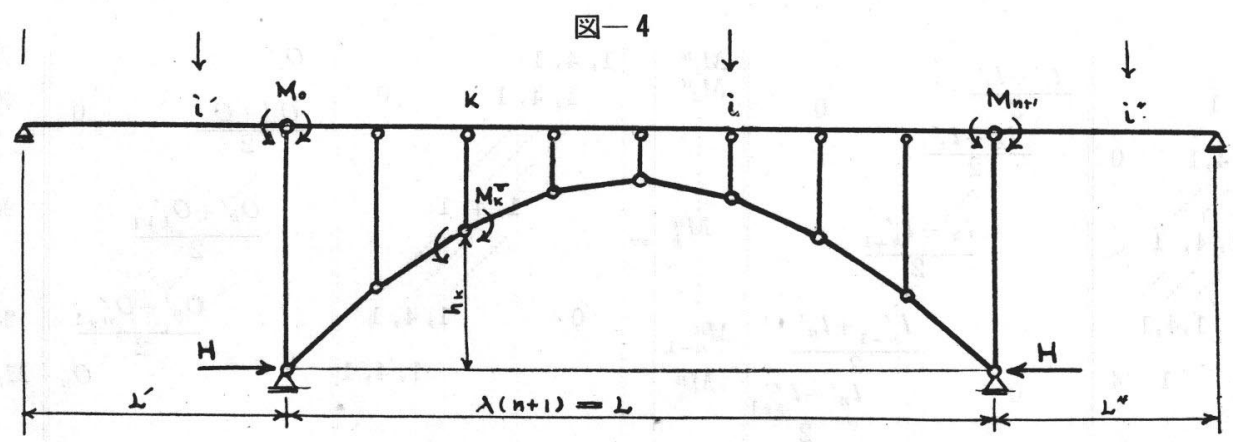

法に四連モーメントの定理が利用されるが，ここでは Castigliano の定理を用いて基本式を求めることとする。 今中央径間のみを切り出して考光て見よう。 $M_{0 i}, M_{n+1, i}$ と $H_{i}$ は既知とし格点 $i$ 飞単位荷重が載荷されたとき 格点 $k$ のすぐ右側で枌を切りモーメントの平衡条件を求めると

$$
M^{\circ}{ }_{k i}+M^{u}{ }_{k i}=\mathfrak{M}_{k i}-h_{k} H_{i}+\frac{n+1-k}{n+1} M_{0 i}+\frac{k}{n+1} M_{n+1, i}
$$

が得られる。単純バりの両 $A B$ に曲げモーメント $M_{A} M_{B}$ が加わつたときとハリと蓄えられるヒズ エネルギ 一は

$$
W_{A B}=\frac{l}{6 E J}\left(M_{A}^{2}+M_{A} M_{B}+M_{B}^{2}\right)
$$

で与兄れるゆえ (1)式で示した曲げモーメントと直応力により中央径間に蓄えられるヒズミエネルギーWは 
$W=\sum_{k=1}^{n+1} \frac{O_{k}}{6 E J_{k}}\left(M_{k-1}^{\circ 2}+M_{k-1}^{\circ} M_{k}^{\circ}+M_{k}^{\circ 2}\right)+\sum_{k=1}^{n+1} \frac{U_{k}}{6 E J_{k}^{u}}\left(M_{k-1}^{u u^{2}}+M_{k-1}^{u} M_{k}^{u}+M_{k}^{u^{2}}\right)+\sum_{k=1}^{n+1} \frac{U_{k}}{2 E F_{k}^{u}} N_{k}^{2}$

で与えられる。簡単のため指標 $i$ は省略した。Castigliano の定理により $\partial W / \partial M_{k}^{u}=0 \quad(k=1,2, \cdots, n-1, n)$ が得られる。今 図一 5 に示したようにアーチ部格点 $k$ に格点モーメント $M_{k}^{u}$ を加光ると補剛桁格点 $k$ に $\bar{M}_{R}^{\circ}=$

図- 5

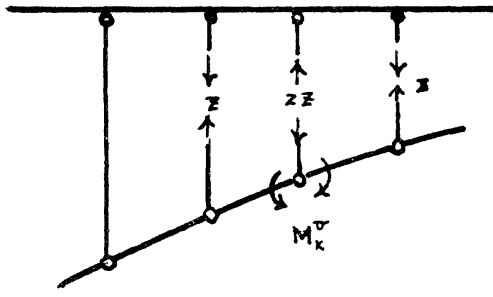

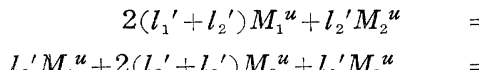
ー $M_{k}^{u}$ なる曲ゲモーメントが生じ他の格点にはモーメントを生じない よつて

$$
\frac{\partial M_{k}^{\circ}}{\partial M_{k}^{u}}=-1, \frac{\partial M_{r}^{\circ}}{\partial M_{k}^{u}}=0, \frac{\partial M_{r}^{\circ}}{\partial M_{k}^{u}}=0
$$

なる関係が得られる。また端部の支承条件より $M_{0}{ }^{u}, M_{n+1}^{u}=0$ であ る。以上の条件を用いて $\partial W / \partial M_{k}^{u}=0$ を求め (1) 式の関係を入れ て整理すれば次の $n$ 元連立一次方程式が得られる。

$=O_{1}{ }^{\prime} M_{0}+2\left(O_{1}{ }^{\prime}+O_{2}{ }^{\prime}\right) \mathfrak{N}_{1}+O_{2}{ }^{\prime} \mathfrak{R}_{2}$

$$
=\quad O_{2}{ }^{\prime} \mathfrak{R}_{1}+2\left(O_{2}{ }^{\prime}+O_{3}{ }^{\prime}\right) \mathfrak{R}_{2}+O_{3}{ }^{\prime} \mathfrak{R}_{3}
$$$$
l_{k}{ }^{\prime} M_{k-1}^{u}+2\left(l_{k}{ }^{\prime}+l_{k+1}^{\prime}\right) M_{k}^{u}+l_{k+1}^{\prime} M_{k+1}^{u}=O_{k}{ }^{\prime} \mathfrak{N}_{k-1}+2\left(O_{k}{ }^{\prime}+O_{k+1}^{\prime}\right) \mathfrak{N}_{k}+O_{k+1}^{\prime} \mathfrak{R}_{k+1}
$$

$$
l_{n+1}^{\prime} M_{n-2}^{u}+2\left(l_{n-1}^{\prime}+l_{n}^{\prime}\right) M_{n-1}^{u}+l_{n}^{\prime} M_{n}^{u}=O_{n-1}^{\prime} \Re_{n-2}+2\left(O_{n-1}^{\prime}+O_{n}{ }^{\prime}\right) \mathfrak{N}_{n-1}+O_{n}{ }^{\prime} \mathfrak{N}_{n}
$$$$
l_{n}{ }^{\prime} M_{n-2}^{u}+2\left(l_{n-1}^{\prime}+l_{n+1}^{\prime}\right) M_{n}^{u}=O_{n}^{\prime} \mathfrak{N}_{n-1}+2\left(O_{n}{ }^{\prime}+O_{n+1}^{\prime}\right) \mathfrak{N}_{n}+O_{n+1}^{\prime} M_{n+1}
$$

ここで $\quad \mathfrak{N}_{k}=\mathfrak{M}_{k}-h_{k} H+\frac{n+1-k}{n+1} M_{0}+\frac{k}{n+1} M_{n+1}$

これを Matrix で表示すれば

$$
\begin{aligned}
& 2\left(l_{1}{ }^{\prime}+l_{2}{ }^{\prime}\right), l_{2}{ }^{\prime} \\
& l_{2}{ }^{\prime}, 2\left(l_{2}{ }^{\prime}+l_{3}{ }^{\prime}\right), l_{3}{ }^{\prime} l_{k}{ }^{\prime} \\
& 0 \\
& l_{n}^{\prime}, 2\left(l_{n}^{\prime}+l_{n+1}^{\prime}\right), l_{k+1}^{\prime} \\
& l_{n}^{\prime}, 2\left(l_{k}^{\prime}+l_{k+1}^{\prime}\right), \ddots_{n} \\
& l_{n}^{\prime}, 2\left(l_{n}^{\prime}+l_{n+1}^{\prime}\right) \\
& O_{1}{ }^{\prime}, 2\left(O_{1}{ }^{\prime}+O_{2}{ }^{\prime}\right), O_{2}{ }^{\prime} \\
& \mathrm{O}_{2 \ell}, 2\left(\mathrm{O}_{2}{ }^{\prime}+\mathrm{O}_{3}{ }^{\prime}\right), \mathrm{O}_{3}{ }^{\prime} \\
& 0 \\
& \dddot{O}_{k}{ }^{\prime}, 2\left(\grave{O}_{k}{ }^{\prime}, O_{k+1}\right), O_{k+1}^{\prime} \\
& O_{n-1}^{\prime}, \because\left(O_{n-1}^{\prime}+O_{n}{ }^{\prime}\right) O_{n}^{\prime} \\
& O_{n}^{\prime}, 2\left(O_{n}^{\prime}+O_{n+1}^{\prime}\right), O_{n+1}^{\prime} \quad \begin{array}{l}
\mathfrak{N}_{n} \\
M_{n+1}
\end{array}
\end{aligned}
$$

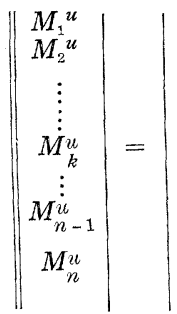

ここで隣り合つた格間の断間の断面定数は注等しいということを仮定すれば（5）式は $l_{k}{ }^{\prime} \doteqdot l_{k+1}{ }^{\prime}, O_{k}{ }^{\prime}=O_{k+1}{ }^{\prime}$ より

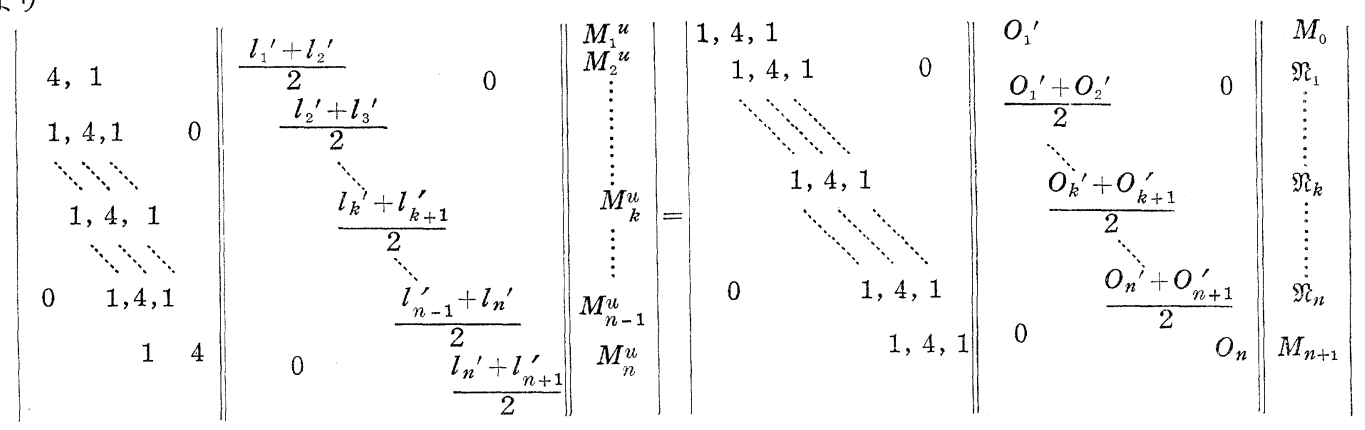

と畫ける。よつて格点モーメント $M_{k}^{u}(k=1,2, \cdots n-1, n)$ は

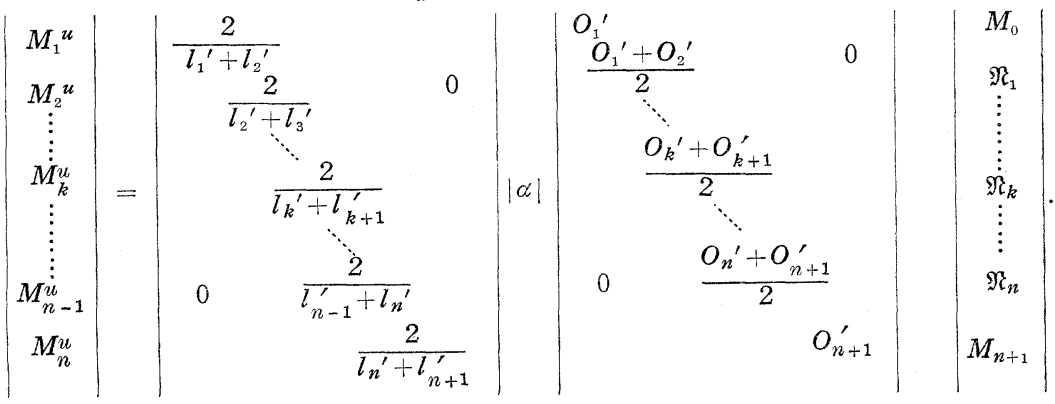


で与えられる。ここで

$$
|\alpha|=\left|\begin{array}{rr}
4,1 & \\
1,4,1 & 0 \\
1,4,1 \\
0 & 1,4,1 \\
& 1,4,1
\end{array}\right|^{-1}\left|\begin{array}{rrr}
1,4,1 & \\
1,4,1 & 0 \\
\ddots & 1,4,1 \\
0 & 1,4,1 \\
& & 1,4,1
\end{array}\right|
$$

右辺第 1 番目の Matrix の第 1 列と第 $n$ 列の要素を $a_{k 1}, a_{k n}$ とすれば, $a_{k_{1}}=a_{n+1-k, n}$ であり $a_{k n}$ は $1,-4,15$, $-56,209 \cdots \cdots-\left|N_{r}\right|=4\left|N_{r-1}\right|-\left|N_{r-2}\right| \cdots \cdots$ 皂る数列の $k$ 番目の数を $n+1$ 番目の数で割つた值である。よつて

$$
|\alpha|=\left|\begin{array}{ccccccc}
a_{11} & 1 & & & & & a_{1 n} \\
& & & & & \\
a_{21} & & 1 & & 0 & a_{2 n} \\
\vdots & & \ddots & & & \vdots \\
a_{k 1} & & 0 & 1 & & & a_{k n} \\
\vdots & & & \ddots & & \vdots \\
a_{n-1,1} & & & & 1 & & a_{n-1 n} \\
& & & & 1 & \\
a_{n 1} & & & & & & a_{n n}
\end{array}\right|
$$

で与えられるゅえ結局 (6) 式は簡単に

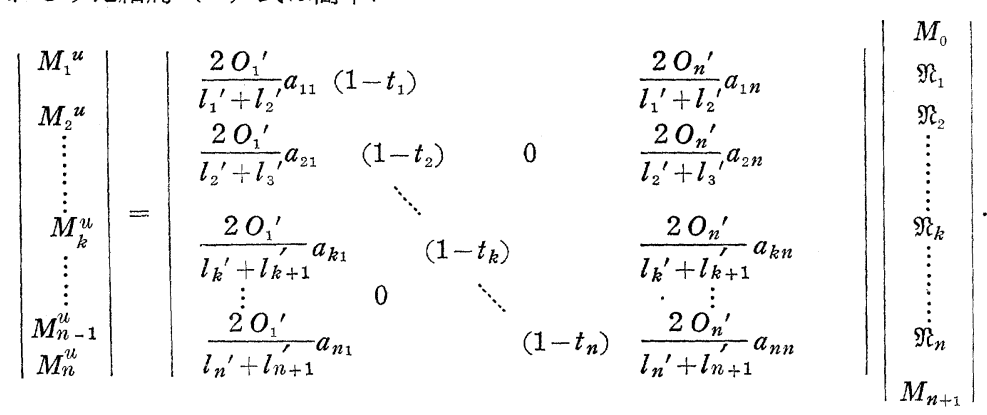

で与兄られる。よつて格点モーメント $M^{\circ}{ }_{k i}, M_{k i}^{u}$ は次式で与兄られる。

$$
\left.\begin{array}{l}
M_{k i}^{\circ}=t_{k}\left(\mathfrak{M}_{k i}-h_{k} H_{i}\right)+\dot{b}_{k 0}^{\circ} M_{0 i}+b_{k, n+1}^{\circ} M_{n+1, i} \\
M_{k i}^{u}=\left(1-t_{k}\right)\left(\mathfrak{M}_{k i}-h_{k} H_{i}\right)+b_{k_{0}}^{u} M_{0 i}+b_{k n+1}^{u} M_{n+1, i}
\end{array}\right\}
$$

ここで $\quad b_{k 0}^{\circ}=\frac{n+1-k}{n+1} t_{k}-\frac{2 O_{1}^{\prime}}{l_{k}{ }^{\prime}+l_{k+1}^{\prime}} a_{k 1}, \quad \dot{b}_{k n+1}^{\circ}=\frac{k}{n+1} t_{k}-\frac{2 O_{1}{ }^{\prime}}{l_{k}{ }^{\prime}+l_{k+1}^{\prime}} a_{k n}, b_{k 0}^{u}=\frac{n+1-k}{n+1}\left(1-t_{k}\right)$

$$
+\frac{2 O_{1}^{\prime}}{l_{k}^{\prime}+l_{k+1}^{\prime}} a_{k 1}, \quad b_{k n+1}^{u}=\frac{k}{n+1}\left(1-t_{k}\right)+\frac{2 O_{1}^{\prime}}{l_{k}^{\prime}+l_{k+1}^{\prime}} a_{k n}
$$

である。

\section{（2）支柱応力の算出}

支柱応力は格点 $k$ の両隣の格点 $(k-1),(k+1)$ の $k$ 側の点で切り (図一 6 参照) 力の平衡を考光れば

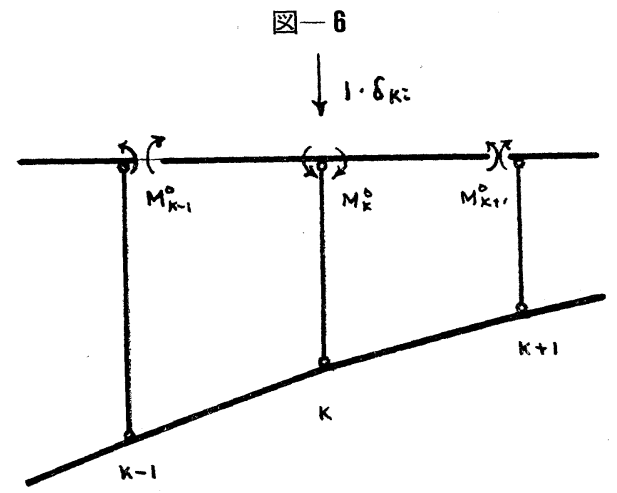

$$
Z_{k i}=-\frac{1}{\lambda}\left(M_{k-1, i}^{\circ}-2 M_{k i}^{\circ}+M_{k+1, i}^{\circ}\right)-1 \cdot \delta_{k i}
$$

をうる。ただし $\delta_{k i}=1 \quad k=i, \delta_{k i}=0 \quad k \neq i \quad$ である。

上式に (9) 式の関係を入れて整理すると支柱応力として

$$
\begin{gathered}
Z_{k i}=-\left(1-t_{k}\right) \delta_{k i}-t_{k} \frac{-h_{k-1}+2 h_{k}-h_{k+1}}{\lambda} H_{i} \\
-6 a_{k_{1}} \frac{2 O_{1}^{\prime}}{\lambda\left(l_{k}^{\prime}+l_{k+1}^{\prime}\right)} M_{0 i}-6 a_{k n} \frac{2 O_{n^{\prime}}}{\lambda\left(l_{k}^{\prime}+l_{k+1}^{\prime}\right)} M_{n+1 i} \\
\left(i=i, i^{\prime}, i^{\prime \prime}\right) \ldots \ldots \ldots \ldots \ldots \ldots \ldots \ldots \ldots \ldots \ldots \ldots \ldots(11)
\end{gathered}
$$

が得られる。

\section{(3) 支点モーメントの算出}

補剛枌のみを取り出して 3 径閒の連続桁と考えて前節で求 めた支柱応力を各格点に荷重として加兄て，支点モーメントは水平反力を含んだ形で求めることができるが，こ 
こでは Cartigliano の定理を用い補剛桁の撓角を支点上で求めその撓角により支点モーメントを算出する。尔ず 中央径間を取り出し，乙れ支点モーメントを加えたとき桁蓄兄られるヒズミエネルギーは今求めようとし ている補岡析端の部材のみ正確に計算し他は近似的に求めると次式で与えられる。

$$
W=\sum_{k=2}^{n+1} \frac{O_{k}}{2 E J_{k}{ }^{\circ}} M_{k}^{\circ}{ }^{2}+\sum_{k=1}^{n+1} \frac{U_{k}}{2 E J_{k}^{u b}} M_{k}^{u 2}+\frac{O_{1}}{b E J_{1}^{\circ}}\left(M_{0}^{\circ}+M_{0}^{\circ} M_{1}^{\circ}+M_{1}^{2}\right)+\sum_{k=1}^{n+1} \frac{U_{k}}{2 E J_{k}^{u b}} N_{k}{ }^{2}
$$

中央径間飞端モーメント $M_{0}, M_{n+1}$ を加光ることにより生じる水平反力を $H M=\Delta H\left(M_{0}+M_{n+1}\right)$ と置けば

$$
\begin{aligned}
& \frac{\partial M_{k}^{\circ}}{\partial M_{0}}=\left(b_{k 0}^{\circ}-\Delta H t_{k} h_{k}\right), \frac{\partial M_{k}^{u}}{\partial M_{0}}=\left(b_{k 0}^{u}-\Delta H\left(1-t_{k}\right) h_{k}\right) \frac{\partial M_{k}^{\circ}}{\partial M_{n+1}}=\left(b_{k n+1}^{\circ}-\Delta H t_{k} h_{k}\right), \frac{\partial M_{k}^{u}}{\partial M_{n+1}} \\
= & \left(b_{k}^{u}, n+1-\Delta H\left(1-t_{k}\right) h_{k}\right)
\end{aligned}
$$

なる関係が得られこれより $W$ を $M_{0}, M_{n+1}$ で偏分して得られる補剛桁端の撓角は

$$
\begin{aligned}
& E J_{c} \theta_{0 i}=\bar{C}_{1} M_{0 i}+C_{2} M_{n+1 i}+C_{0 i} \\
& E J_{c} \theta_{n+1 i}=C_{2} M_{0 i}+\bar{C}_{1} M_{n+1 i}+C_{n+1 i}
\end{aligned}
$$

で与えられる。ここで $\theta_{0 i}, \theta_{n+1, i}$ は中央径間格点 $i$ そ単位荷重が載荷されたときの補剛桁端格点 $0, n+1$ 角の撓 であり $M_{0}, M_{n+1}$ と同方向回転するものを正とする。また $\bar{C}_{1}, C_{2}, C_{0 i}, C_{n+1, i}$ は $H_{i} L$ をロ一ゼ桁としての水平 反力とすれば

$$
\begin{aligned}
& \bar{C}_{1}=\sum_{k=1}^{n+1}\left\{O_{k}{ }^{\prime}\left(b_{k 0}^{\circ}-\Delta H t_{k} h_{k}\right)^{2}+u_{k}{ }^{\prime}\left(b_{k 0}^{u}-\Delta H\left(1-t_{k}\right) h_{k}\right)^{2}\right\}+\frac{O_{1}^{\prime}}{3}\left\{1+\left(b_{10}^{\circ}-\Delta H t_{1} h_{1}\right)-2\left(b_{10}^{\circ}-t_{1} h_{1} \cdot \Delta H\right)^{2}\right\} \\
& C_{2}=\sum_{k=1}^{n+1}\left\{O_{k}{ }^{\prime}\left(b_{k n+1}^{\circ}-\Delta H t_{k} h_{k}\right)\left(b_{k 0}^{\circ}-\Delta H t_{k} h_{k}\right)+U_{k}{ }^{\prime}\left(b_{k n+1}^{u}-\Delta H\left(1-t_{k}\right) h_{k}\right) \times\left(b_{k 0}^{u}-\Delta H\left(1-t_{k}\right) h_{k}\right)\right\} \\
& C_{o i}=\sum_{k=1}^{n+1}\left(\mathfrak{M}_{k i}-h_{k} H_{i}\right)\left\{O_{k}{ }^{\prime}\left(b_{k 0}^{\circ}-\Delta H t_{k} h_{k}\right) t_{k}+U_{k}{ }^{\prime}\left(b_{k 0}^{u}-\Delta H\left(1-t_{k}\right) h_{k}\right)\left(1-t_{k}\right)\right\} \\
& C_{n+1 i}=\sum_{k=1}^{n+1}\left(\mathfrak{M}_{k i}-h_{k} H_{i}\right)\left\{O_{k}{ }^{\prime}\left(b_{k}^{\circ}{ }^{\circ}+1-\Delta H t_{k} h_{k}\right) t_{k}+U_{k}{ }^{\prime}\left(b_{k n+1}^{u}-\Delta H\left(1-t_{k}\right) h_{k}\right)\left(1-t_{k}\right)\right\} \cdots \cdots \cdots(13 \mathrm{a}-\mathrm{d})
\end{aligned}
$$

で与兄られ。

側径間の㩖角は断面 2 次モーメントが一定ならば

$$
E J_{c} \theta_{0 i}{ }^{\prime}=\frac{L^{\prime} J_{c}}{3 J^{\prime}} M_{0 i}{ }^{\prime} \quad E J_{c} \theta_{n+1 i}^{\prime \prime}=\frac{L^{\prime} J_{c}}{3 J^{\prime \prime}} M_{n+1 i}^{\prime \prime}
$$

で与えられる。ここで $\theta_{0}{ }^{\prime}, J^{\prime}, L^{\prime}$ は支点 0 側の $\theta^{\prime \prime}{ }_{n+1 i}, J^{\prime \prime}, L^{\prime \prime}$ は支点 $n+1$ 側の側径間の撓角, 断面 2 次モ一 メント，支間長である。

支点上での連続の条件より

$$
\begin{aligned}
& \theta_{0 i}=-\theta_{0 i}{ }^{\prime}, \quad \theta_{n+1 i}=-\theta_{n+1 i}^{\prime \prime} \\
& M_{0 i}=M_{0 i}{ }^{\prime}, M_{n+1 i}=M_{n+1 i}^{\prime \prime}
\end{aligned}
$$

なる関係が成立し，これ代 (12)(14) 式を代入すれば

$$
\begin{aligned}
& C_{1}{ }^{\prime} M_{0 i}+C_{2} M_{n+1 i}=-C_{0 i} \\
& C_{1}{ }^{\prime \prime} M_{n+1 i}+C_{2} M_{0 i}=-C_{n+1 i}
\end{aligned}
$$

を得る。これょり $M_{0 i}, M_{n+1 i}$ を求めることができる。ここで $C_{1}{ }^{\prime}=\bar{C}_{1}+\frac{L^{\prime}}{3 J^{\prime}}, C_{1}{ }^{\prime \prime}=\bar{C}_{1}+\frac{L^{\prime \prime}}{3 J^{\prime \prime}}$ である。 今 $C_{1}{ }^{\prime}=C_{1}{ }^{\prime \prime}=C_{1}$ なるときは, 支点モーメントは

$$
\begin{aligned}
& M_{0 i}=\frac{-C_{1} C_{o i}+C_{2} C_{n+1 i}}{C_{1}{ }^{2}-C_{2}{ }^{2}} \\
& M_{n+1 i}=\frac{-C_{1} C_{n+1}+C_{2} C_{0 i}}{C_{1}{ }^{2}-C_{2}{ }^{2}}
\end{aligned}
$$

で与えられる。唄径間に荷重があるときは (14) 式は

$$
\left.\begin{array}{l}
E J_{c} \theta_{0 i}{ }^{\prime}=\frac{L^{\prime} J_{c}}{3 J^{\prime}} M_{0 i^{\prime}}+C_{0 i^{\prime}} \\
E J_{c} \theta_{n+1 i}^{\prime \prime}=\frac{L^{\prime} J_{c}}{3 J^{\prime \prime}} M_{n+1 i}^{\prime \prime}+C_{n+1 i}^{\prime \prime}\left(i=i^{\prime}, i^{\prime \prime}\right)
\end{array}\right\}
$$

となり, $C_{0 i}, C_{n+1 i}=0$ となる。ここで $C_{0 i}{ }^{\prime}, C_{n+1 i}^{\prime \prime}$ は側径間の単純バリとしての格点 $0, n+1$ での撓角を $E J_{c}$ 倍したものである。よつて(16) 式は

$$
\begin{aligned}
& C_{1}{ }^{\prime} M_{0 i}+C_{2} M_{n+1 i}=-C_{0 i}{ }^{\prime} \\
& C_{1}{ }^{\prime \prime} M_{n+1 i}+C_{2} M_{0 i}=-C_{n+1 i}^{\prime \prime} \quad\left(i=i^{\prime}, i^{\prime \prime}\right)
\end{aligned}
$$




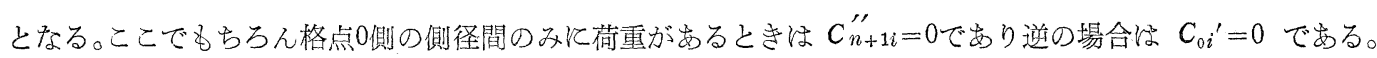
また $C_{1}{ }^{\prime}=C_{1}{ }^{\prime \prime}=C_{1}$ の場合ほ (17) 式は次式となる。

$$
\left.\begin{array}{l}
M_{0 i}=\frac{-C_{1} C_{0 i}{ }^{\prime}+C_{2} C_{n+1 i}^{\prime \prime}}{C_{1}^{2}-C_{2}{ }^{2}} \\
M_{n+1 i}=\frac{-C_{1} C_{n+1 i}^{\prime \prime}+C_{2} C_{0 i}{ }^{\prime}}{C_{1}^{2}-C_{2}{ }^{2}}\left(i=i^{\prime} \text { または } i^{\prime \prime}\right)
\end{array}\right\}
$$

\section{（4）支点モーメントによる水平反力}

(2)式で与兄られる内部ヒズミエネルギーをHで扁分として0と置けば

$$
\begin{aligned}
& \Delta H=\left[\sum _ { k = 1 } ^ { n + 1 } \left[O_{k}^{\prime}\left\{b_{k-10}^{\circ}\left(2 t_{k-1} h_{k-1}+t_{k} h_{k}\right)+b_{k 0}^{\circ}\left(2 t_{k} h_{k}+t_{k-1} h_{k-1}\right)\right\}+U_{k}^{\prime}\left\{b _ { k - 1 0 } ^ { u } \left(2\left(1-t_{k}\right) h_{k-1}\right.\right.\right.\right. \\
& \left.\left.\left.\left.+\left(1-t_{k}\right) h_{k}\right)+b_{k 0}^{u}\left(2\left(1-t_{k}\right) h_{k}+\left(1-t_{k-1}\right) h_{k-1}\right)\right\}\right]\right] \\
& {\left[\sum _ { k = 1 } ^ { n + 1 } \left[O_{k}^{\prime}\left\{t_{k-1} h_{k-1}\left(2 t_{k-1} h_{k-1}+t_{k} h_{k}\right)+t_{k} h_{k}\left(2 t_{k} h_{k}-t_{k-1} h_{k-1}\right)\right\}+U_{k}^{\prime}\left\{( 1 - t _ { k - 1 } ) h _ { k - 1 } \left(2\left(1-t_{k-1}\right)\right.\right.\right.\right.} \\
& \left.\left.\left.\left.+\left(1-t_{k}\right) h_{k}\right)+\left(1-t_{k}\right) h_{k}\left(2\left(1-t_{k}\right) h_{k}+\left(1-t_{k}\right) h_{k-1}\right)\right\}\right]+\sum_{k=1}^{n+1} \frac{6 U_{k} J_{c}}{\lambda^{2} F_{k}^{u}} \sec ^{2} \beta\right]^{-1} \ldots
\end{aligned}
$$

が得られる。（18）式は少々繁雑でめるので，もしアーチ部のアーチとしての水平反力の影響線縦距が正確代計 算されているときは（2）節で求めた支柱応力をアーチ载せ

$$
\Delta H=\frac{\left(6 \sum_{k=1}^{n} H_{k}^{A} a_{k} \frac{2 O_{1}^{\prime}}{l_{k}{ }^{\prime}+l_{k+1}^{\prime}}\right)}{\lambda\left(1-\sum_{k=1}^{n} t_{k} \frac{-h_{k-1}+2 h_{k}-h_{k+1}}{\lambda} H_{k}^{A}\right)}
$$

を用いてもよい。ここで $H_{k}^{A}$ はーチ部のみのアーチとしての水平反力影響線縦距である。

(5) 水平反力

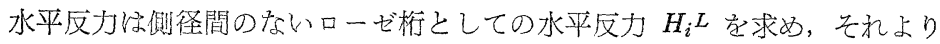

$$
H_{i}=H_{i}{ }^{L}+\Delta H\left(M_{0 i}+M_{n+1 i}\right)
$$

として求めることができる。もちるん惐重が側径間にあるときは $H_{i} L=0$ である。

\section{3. 補剛衍にラーメンを用いた場合その他の補剛アーチ祜}

図一2に示したようと端柱を補刷桁に剛結しラーメン構造に補剛枌がなつている場合について考えてみよう。 一般的飞前章の補剛アーチ橋の場合は端柱は応力的に見て余裕が㐫る場合が多く，一方側径間の応力はかなり大 きくなる場合が多いのでこの型式は応力的にる有利な場合が多いと思われる。構造的にも端柱上飞とンジを設け る必要がないので有利である。

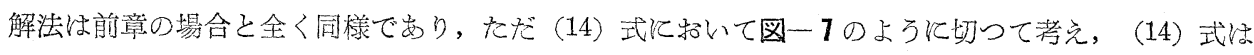

$$
\left.\begin{array}{l}
E J_{c} \theta_{0 i}{ }^{\prime}=\frac{J_{c}}{3 \frac{J^{\prime}}{L^{\prime}}+3 \frac{J_{h}}{h_{0}}} M_{0 i}{ }^{\prime}+\frac{1}{1+\frac{J_{h} L^{\prime}}{h_{0} J^{\prime}}} C_{0 i}^{\prime} \\
E J_{c} \theta_{n+1 i}^{\prime}=\frac{J_{c}}{3 \frac{J^{\prime \prime}}{L^{\prime \prime}}+3 \frac{J_{h}}{h_{0}}} M_{n+1 i}^{\prime \prime}+\frac{1}{1+\frac{J_{h} L^{\prime \prime}}{h_{0} J^{\prime \prime}}} C_{n+1 i}^{\prime \prime}
\end{array}\right\}
$$

として計算ずればよい。

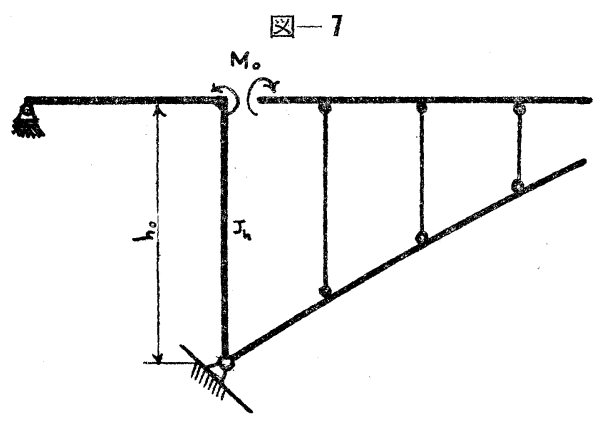

また図ー8に示した型式のものは鋼橋では用いられ ることが少ないと思われるが，既存のコンクリート固 定アーム橋在交通量あるいは荷重の增大効応して補

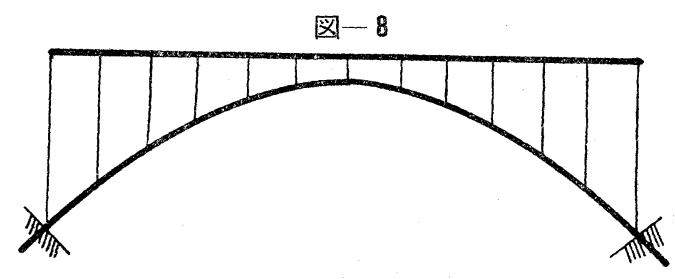


強するとき亿利用価值があると思われる。この場合の解法は前節での場合の符標 $O$ と Uすずて逆にして $\theta{ }_{0 i}^{u}$, $\theta{ }_{n+1 i}^{u}=0$ と置いて求めることができる。

\section{*4. 上路式ローゼ桁支点がアーチ支点上にない場合の影響について}

上路式ローゼ枌を架設する場合補剛桁の支点を理論通りアーチ支点への鉛直線に設けるためには禣剛枌の橋台 を突き出させるか，アーチの支点をアンカーブロック中に埋め込をかしなければならないのが常である。これを 避けるためと補剛析の支点を少々ずらした方が有利な場合が多い。そこでその場合の近似解法を試みる。

エネルギー法により，ローゼ枌のごとく簡単な連立方程式を得る重要な要素は

a) 格点飞不静定モーメントを加えた場合同じ格点の他の弦材に逆周りの等しい值のモーメントが現われる。

b）格点に不静定モーメントを加光たとき，そのモーメントの影響はその格点を㣣えでいる格間のみに現われ る，ということである。すなわち $\partial M_{R}^{u} / \partial M_{k}^{\circ}=-1, \partial M_{r}^{u} / \partial M_{k}^{\circ}=0(k \neq r)$ という条件を満足しないと隣り合つ た 3 項の不静定力の夕からなる連立方程式は得られない。

今上弦材格点をヒンジと考光格点 1 飞不静定曲げモーメント $M_{1}^{\circ}$ 学加光よう (図一 9 参照)。そのとき生じる 格点反力は

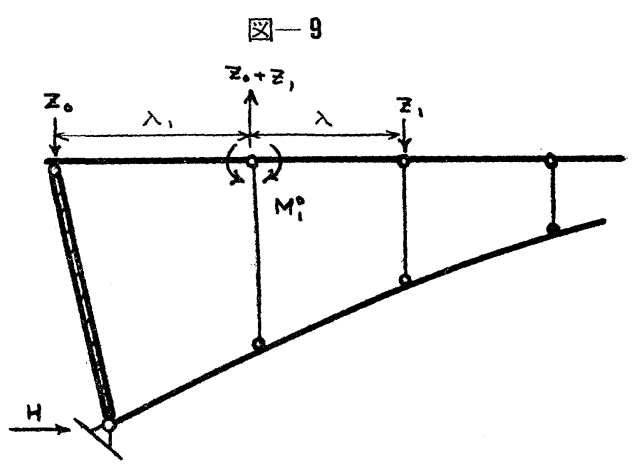

$$
\begin{aligned}
& \text { 格点0V批いて } Z_{0}=\frac{M_{1}^{\circ}}{\lambda_{1}} \\
& \left.\begin{array}{ll}
\text { 格点 } 1 \text { 亿㧐いて } Z_{1}=-\left(\frac{1}{\lambda_{1}}+\frac{1}{\lambda}\right) M_{10}{ }^{\circ} \\
\text { 格点 } 2 \text { 亿括いて } Z_{2}=\frac{M_{1}^{\circ}}{\lambda}
\end{array}\right\}
\end{aligned}
$$

である。b）の条件を満たすように下弦材格点で $M_{1}$ そよる曲げモーメントが 0 となるためには次の格点荷 重を仮加觉てや礼よ゙よ。

$$
\Delta Z=\left(Z_{2}-Z_{1}\right) \frac{n+1}{n-1}
$$

このとき下弦材格点に生じる曲げモーメントは

$$
M=-\left(Z_{1}+\frac{n}{n+1} \Delta Z\right) \lambda=-\frac{n Z_{2}-Z_{1}}{n-1} \div-Z_{2} \lambda=-M_{1}^{\circ}
$$

よつて近似的に a)の条件を満足する。そこで格点 $1, n$ に格点モーメント $M_{1}{ }^{\circ}, M_{n}{ }^{\circ}$ に比例して現われる荷 重一 $\Delta Z$ を仮りと加兄てやれば普通ローゼ枌と全く同様の結果が得られる。そこで普通のローゼ桁と同様に計算 して得られた格点モーメント $M_{1}^{\circ}, M_{n}{ }^{\circ}$ より $\Delta Z_{1}, \Delta Z_{n}$ を求めその分だけ余計に後で加光てやれば近似的に支点 のずれは計算できる。

$$
\text { 図-10 }
$$

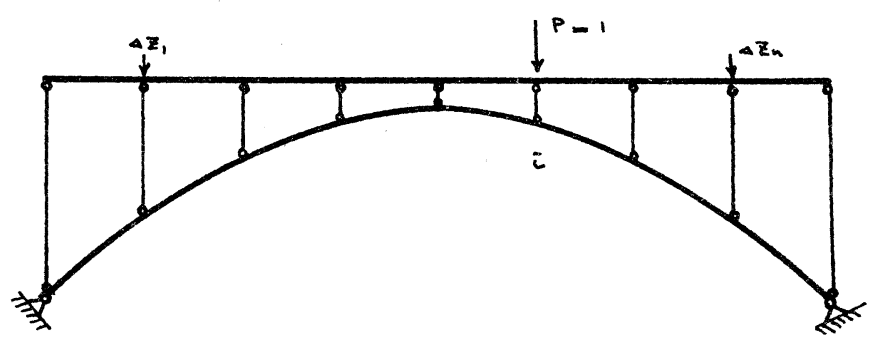

すなわち $\Delta Z_{1}=t_{1}\left(\mathfrak{M}_{i}-h_{1} H_{i}\right)\left(\frac{1}{\lambda}-\frac{1}{\lambda_{1}}\right) \frac{n+1}{n-1}$

$$
\begin{aligned}
& \Delta Z_{2}=t_{n}\left(M_{n i}-h_{n} H_{i}\right)\left(\frac{1}{\lambda}-\frac{1}{\lambda_{n}}\right) \frac{n+1}{n-1} \\
& M_{k i}^{\circ}=M_{k i}^{\circ L}+\Delta Z_{1} M_{R 1}^{\circ}{ }^{L}+\Delta Z_{n} M_{R n}^{\circ} \\
& M_{R i}^{u}=M_{R i}^{u L}+\Delta Z_{1} M_{R n}^{u L}+\Delta Z_{n} M_{k n}^{u L}
\end{aligned}
$$




\section{5. 計算例および実験值}

図一11 は 図一1の型式の桁について模型実験を行い, その実験值より得られた水平反力括よび支点モーメン ト，1/4点， $1 / 2$ 点の格点モーメント影響線縦距と理論値とを対此せしめたものである。これより本理論によつた 計算值と実験值はかなりよく一致していることが認められる。な物使用模型寸法は下の通りで岗る。

図一11 水平反力, 格線モーメント影響点縦距理論值, 実験值
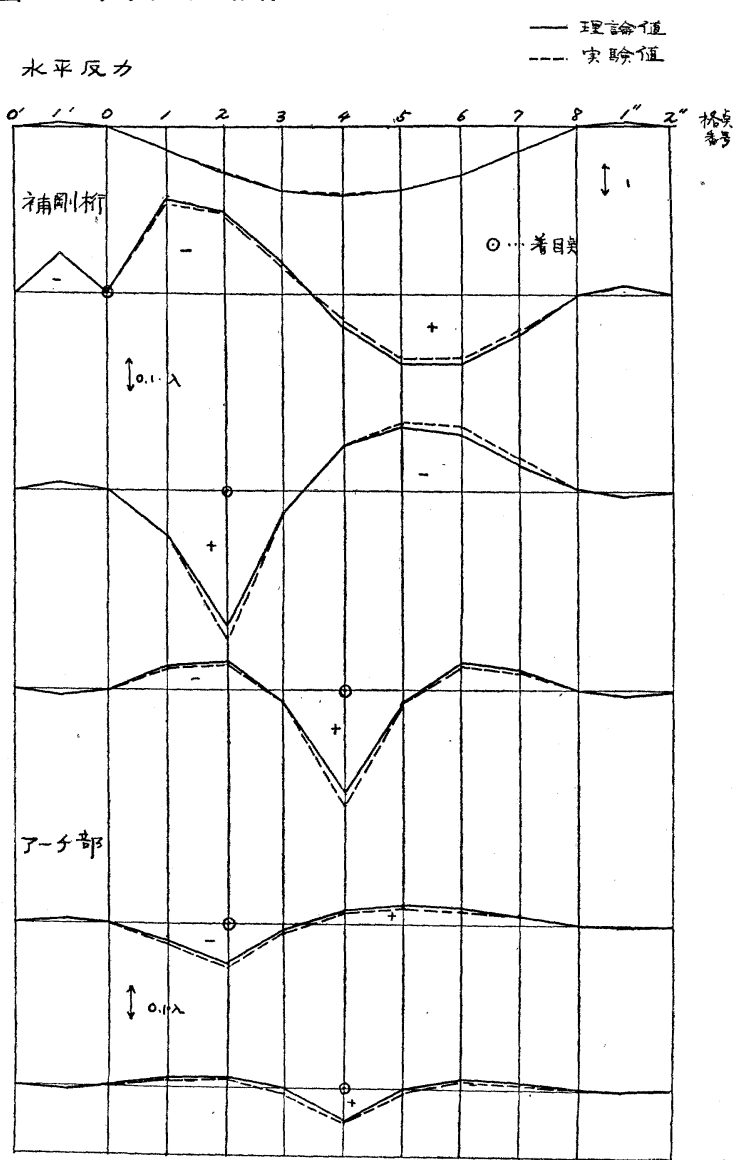

$L=480 \mathrm{~cm}$

$n+1=8$

$f=64 \mathrm{~cm}$

$J_{k}^{\circ}=2.93 \mathrm{~cm}^{4} \quad(k=1,2 \cdots 8)$

$J_{R}^{u}=0.885 \mathrm{~cm}^{4} \quad(k=1,2 \cdots 8)$

使用材料㤝鍮である。

曲げモーメント分配率 $t_{k}$ は支間中央で $t_{k} \div 0.756$ である。

\section{参考文献}

1) 平井敦：鋼 橋 III, 1957, 技報堂

2)一般の忘用力学の教科書 